\title{
Uji daya hambat ekstrak daun bayam petik (Amaranthus hybridus L.) terhadap pertumbuhan bakteri Staphylococcus aureus
}

\author{
${ }^{1}$ Oktovianus Pormes \\ ${ }^{2}$ Damajanty H. C. Pangemanan \\ ${ }^{3}$ Michael A. Leman \\ ${ }^{1}$ Kandidat Skripsi Program Studi Pendidikan Dokter Gigi Fakultas Kedokteran \\ ${ }^{2}$ Bagian Fisiologi Fakultas Kedokteran \\ ${ }^{3}$ Program Studi Pendidikan Dokter Gigi Fakultas Kedokteran \\ Universitas Sam Ratulangi Manado \\ Email: samuel_pormes@yahoo.com
}

\begin{abstract}
Synthetic antibiotics have certain side effects, therefore, it is necessary to find alternative natural antibacterial materials which is easily available and to be cultivated, inter alia Amaranthus hybridus L. Its leaves contain active compounds, so they might have antibacterial potential. This study was aimed to determine the inhibitory effect of Amaranthus hybridus leaf extract on the growth of Staphylococcus aureus. This was a true experimental study using post test only control group design. This study was conducted at the Microbiology Laboratory of Faculty of Medicine and the Natural Phytochemical Laboratory of Faculty of Mathematics at Sam Ratulangi University. The modified Kirby-Bauer method was used with three wells, containing Amaranthus hybridus leaf extract, the positive control, and the negative control; and with 5 repetitions. The results showed that the average diameters of the inhibition zone of Amaranthus hybridus leaf extract and of the negative control were $0 \mathrm{~mm}$ meanwhile of erythromycin as the positive control was $38.8 \mathrm{~mm}$. Conclusion: Amaranthus hybridus leaf extract had no inhibitory effect on Staphylococcus aureus.
\end{abstract}

Keywords: inhibitory zone, Amaranthus hybridus L, Staphylococcus aureus

\begin{abstract}
Abstrak: Bahan antibiotik sintetik memiliki efek samping, sehingga perlu dicari bahan alternatif yaitu bahan alami yang mudah didapat dan dibudidayakan, salah satunya ialah bayam petik (Amaranthus hybridus L.). Daun bayam petik memiliki potensi antibakteri karena memiliki kandungan senyawa aktif. Penelitian ini bertujuan untuk mengetahui daya hambat ekstrak daun bayam petik terhadap pertumbuhan bakteri Staphylococcus aureus. Jenis penelitian ialah eksperimental murni dengan post test only control group design. Penelitian dilakukan di Laboratorium Mikrobiologi Fakultas Kedokteran dan Labaratorium Fitokimia Fakultas MIPA Unsrat. Metode pengujian yang digunakan ialah modifikasi Kirby-Bauer dengan menggunakan tiga buah sumuran yang diberi ekstrak daun bayam petik, kontrol positif, dan kontrol negatif, sebanyak 5 kali pengulangan. Hasil penelitian menunjukan diameter rerata dari zona hambat yang terbentuk pada sumur dengan ekstrak daun bayam petik dan pada sumur dengan kontrol negatif ialah $0 \mathrm{~mm}$, sedangkan pada sumur yang diberi kontrol positif amoksisilin terjadi resistensi sehingga diganti dengan eritromisin dan didapatkan rerata zona hambat ialah 38,8 mm. Simpulan: Ekstrak daun bayam petik (Amaranthus hybridus L.) tidak memiliki daya hambat terhadap pertumbuhan bakteri Staphylococcus aureus.
\end{abstract}

Kata kunci: daya hambat, Amaranthus hybridus L, Staphylococcus aureus

Kesehatan gigi dan mulut seringkali tidak menjadi prioritas yang utama bagi sebagian orang. Tanpa disadari, gigi dan mulut merupakan pintu gerbang masuknya bakteri 
sehingga dapat mengganggu kesehatan organ tubuh lainnya. Gigi berlubang atau karies gigi masih menjadi masalah utama bagi anak-anak maupun orang dewasa. Oleh sebab itu, hal ini tidak bisa dibiarkan hingga parah karena dapat memengaruhi kualitas hidup, mengakibatkan rasa nyeri, ketidaknyamanan, infeksi akut dan kronis, gangguan makan, dan gangguan tidur. ${ }^{1}$

Karies gigi merupakan salah satu penyakit yang banyak diderita oleh masyarakat. Berdasarkan data Riskesdas tahun 2007 dan 2013, prevalensi masalah gigi dan mulut di Indonesia naik dari $23,4 \%$ menjadi $25,9 \%$. Sulawesi Utara merupakan salah satu provinsi yang menunjukkan kenaikan prevalensi masalah gigi dan mulut, yaitu dari $29,8 \%$ menjadi $31,6 \%$. Berdasarkan data riskesdas 2013, indeks karies yang diukur berdasarkan ratarata indeks DMF-T secara nasional ialah 4,6, sedangkan provinsi Sulawesi Utara yaitu sebesar 5,4. Dari data tersebut, dapat dilihat bahwa indeks kerusakan gigi di Provinsi Sulawesi Utara termasuk kategori tinggi menurut indeks DMF-T dari WHO. ${ }^{2,3}$

Karies gigi akan menyebabkan infeksi yang lebih parah hingga ke saluran akar. Hal ini dapat menyebabkan kerusakan jaringan di sekitar akar gigi yang dapat menyebabkan abses. Sebagian besar (9095\%) infeksi yang terjadi di regio orofasial merupakan infeksi odontogenik, dan sekitar $70 \%$ merupakan lesi periapikal, terutama abses dentoalveolar akut dan abses periodontal. Salah satu bakteri yang berperan dalam infeksi ini ialah Staphylococcus aureus. ${ }^{4,5}$

Lebih dari 30 tipe Staphylococcus dapat menginfeksi manusia namun umumnya infeksi disebabkan oleh Staphylococcus aureus. Suzuki at al. ${ }^{6}$ (1996) melaporkan bahwa rongga mulut menjadi tempat yang nyaman bagi Staphylococcus aureus. Knighton $^{7}$ (1965) melaporkan adanya Staphylococcus koagulase-positif pada rongga mulut dan hidung dari mahasiswa kedokteran gigi dan mendeteksi adanya mikroorganisme ini pada $47,50 \%$ sampel saliva dan $47,1 \%$ pada fosa nasi. ${ }^{6,7}$
Bahan antibiotik sintetik memiliki efek samping, sehingga perlu dicari bahan alternatif yaitu bahan alami. Bayam merupakan tanaman yang mudah didapatkan dan dibudidayakan. Tanaman bayam dapat tumbuh di iklim panas dan semi-gersang. Dewasa ini, terdapat dua jenis bayam yang dikenal, yaitu bayam liar dan bayam budidaya. Bayam liar terdiri dari dua jenis yaitu bayam berduri dan bayam tanah. Bayam yang sering dikonsumsi ialah bayam budidaya yang terdiri dari dua jenis, yaitu bayam cabut dan bayam petik. Komponen bioaktif yang terdapat pada bayam petik yaitu flavonoid, alkaloid, tanin, saponin, dan fenol. Komponen bioaktif ini yang berperan penting sebagai antibakteri. Penelitian secara in vitro telah menunjukkan bahwa flavonoid, terpenoid, dan steroid secara efektif mampu menghambat pertumbuhan bakteri. Penelitian yang dilakukan oleh Sumitra et al. menggunakan ekstrak akar dari bayam petik pada Staphylococcus aureus mendapatkan diameter zona hambat $20 \mathrm{~mm}$; pada Bacillus subtilis dengan diameter zona hambat $22 \mathrm{~mm}$; dan pada Escherichia coli dengan diameter zona hambat sebesar $21 \mathrm{~mm} .^{8-10}$

Penelitian ini bertujuan untuk mengetahui uji daya hambat ekstrak daun bayam petik (Amaranthus hybridus L.) terhadap pertumbuhan Staphylococcus aureus.

\section{BAHAN DAN METODE}

Jenis penelitian yang digunakan ialah eksperimental murni dengan post test only control group design. Penelitian dilakukan di Laboratorium Farmasi Fakultas MIPA dan Laboratorium Mikrobiologi Fakultas Kedokteran Universitas Sam Ratulangi pada bulan Maret 2016 - Agustus 2016.

Subjek penelitian ialah bakteri Staphylococcus aureus yang dibiakan dari abses rongga mulut di Laboratorium Mikrobiologi Fakultas Kedokteran Universitas Sam Ratulangi. Daun bayam petik (Amaranthus hybridus L.) didapatkan dari Desa Rurukan, Kota Tomohon, Sulawesi Utara dan diekstrak dengan menggunakan etanol $96 \%$. 
Metode pengujian yang digunakan ialah modifikasi Kirby-Bauer dengan menggunakan sumuran. Media MHA disediakan sebanyak lima cawan petri dengan lima belas buah sumur. Setiap cawan Petri berisi satu sumur kelompok intervensi, satu sumur kelompok kontrol positif, dan satu sumur kelompok kontrol negatif. Cawan petri selanjutnya diinkubasi dalam inkubator pada suhu $37^{\circ} \mathrm{C}$ selama 24 jam.

Pengamatan dilakukan selama 24 jam masa inkubasi. Zona bening merupakan petunjuk kepekaan bakteri terhadap bahan antibakteri yang digunakan sebagai bahan uji dan dinyatakan dengan diameter zona hambat. Zona hambat yang terbentuk di sekitar sumur diukur diameter vertical $\left(\mathrm{D}_{\mathrm{V}}\right)$ dan diameter horizontal $\left(\mathrm{D}_{\mathrm{H}}\right)$ dalam satuan milimeter $(\mathrm{mm})$ dengan menggunakan jangka sorong (Gambar 1).

$$
\frac{\mathrm{D}_{\mathrm{V}}+\mathrm{D}_{\mathrm{H}}}{2}
$$

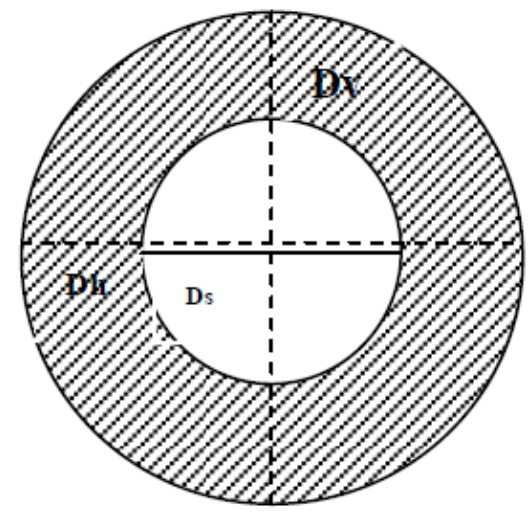

Gambar 1. Pengukuran diameter zona hambat

Keterangan :

$\begin{array}{ll}\text { WUW } & \text { Zona hambat } \\ \mathrm{D}_{\mathrm{V}} & =\text { Diameter vertikal } \\ \mathrm{D}_{\mathrm{H}} & =\text { Diameter horizontal } \\ \mathrm{D}_{\mathrm{S}} & =\text { Diameter sumur }\end{array}$

\section{HASIL PENELITIAN}

Penelitian ini dilakukan sebanyak tiga kali percobaan karena terjadi resistensi pada kontrol positif amoksisilin. Pada percobaan yang pertama dan kedua tidak terdapat zona hambat yang terbentuk pada sumur pertama (kontrol positif amoksisilin), sumur kedua (ekstrak daun bayam petik), dan sumur ketiga (kontrol negatif akuades). Pertumbuhan bakteri setelah masa inkubasi terlihat tidak menjauhi sumur, artinya tidak terdapat zona bening yang terbentuk.

Pada percobaan yang ketiga kontrol positif amoksisilin diganti dengan eritromisin. Hasil penelitian menunjukkan tetap tidak terbentuk zona hambat pada sumur yang diberi ekstrak daun bayam petik dan kontrol negatif akuades, tetapi terbentuk zona hambat pada sumur yang diberi eritromisin (Gambar 2).

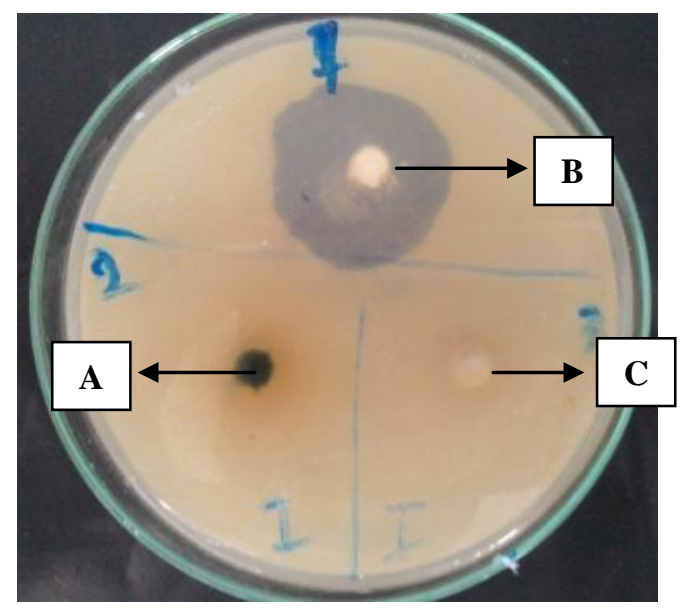

Gambar 2. Percobaan ketiga

Keterangan :

A: Ekstrak daun bayam petik

B: Kontrol positif eritromisin

C: Kontrol negatif akuades

Zona hambat diukur menggunakan jangka sorong dengan satuan milimeter $(\mathrm{mm})$. Pengamatan zona hambat dilakukan dengan cara mengukur diameter horizontal dan diameter vertikal dari zona hambat yang terbentuk disekitar sumur. Kedua diameter tersebut dimasukan ke dalam rumus untuk mencari rerata diameter zona hambat. Perbandingan zona hambat antara kelompok intervensi dan kelompok kontrol dapat dilihat pada Tabel 1. 
Pormes, Pangemanan, Leman: Uji daya hambatekstrak daun bayam petik ...

Tabel 1. Perbandingan diameter zona hambat terhadap Staphylococcus aureus

\begin{tabular}{cccc}
\hline Cawan Petri & \multicolumn{2}{c}{ Diameter zona hambat (mm) } \\
& $\begin{array}{c}\text { Ekstrak daun } \\
\text { bayam petik }\end{array}$ & $\begin{array}{c}\text { Eritromisin } \\
\text { Kontrol (+) }\end{array}$ & $\begin{array}{c}\text { Akuades } \\
\text { Kontrol (-) }\end{array}$ \\
\hline I & 0 & 25,5 & 0 \\
II & 0 & 25 & 0 \\
III & 0 & 55 & 0 \\
IV & 0 & 38 & 0 \\
V & 0 & 50,5 & 0 \\
Total & 0 & 194 & 0 \\
Rerata & 0 & 38,8 & 0 \\
\hline
\end{tabular}

\section{BAHASAN}

Penelitian ini menggunakan uji ekperimental untuk mengetahui adanya efek antibakteri daun bayam petik dalam menghambat pertumbuhan bakteri Staphylococcus aureus. Penelitian dilakukan dengan cara membiakan bakteri Staphylococcus aureus dalam media Müller-Hinton Agar. Pembentukan tiga buah sumur dengan alat pencadang yang diberi ekstrak daun bayam petik, antibiotik eritromisin sebagai kontrol positif, dan akuades sebagai kontrol negatif, kemudian dimasukan inkubator dengan suhu $37^{\circ} \mathrm{C}$ selama 24 jam.

Pada penelitian ini terlihat bahwa telah terjadi resistensi terhadap antibiotik amoksisilin. Hal ini diperkuat dengan penelitian yang dilakukan oleh Olyvia et al. ${ }^{11}$ pada tahun 2015 yang menemukan bahwa lima bakteri dengan morfologi coccus diantaranya Staphylococcus aureus telah menunjukan resistensi terhadap amoksisilin. Penelitiannya juga melaporkan bahwa belum terjadi resistensi pada antibiotik eritromisin karena pada penelitian tersebut nilai konsentrasi hambat minimum eritromisin yang diperoleh masih berada dalam batas normal konsentrasi hambat minimum eritromisin terhadap bakteri Gram positif. Berdasarkan hasil penelitian ini terlihat bahwa eritromisin masih efektif dalam menghambat pertumbuhan bakteri Staphylococcus aureus dengan hasil dari masing-masing pengulangan yaitu $25,5 \mathrm{~mm}, 25 \mathrm{~mm}, 55$ $\mathrm{mm}, 38 \mathrm{~mm}$, dan $50,5 \mathrm{~mm}$ dengan rerata $38,8 \mathrm{~mm}$.
Parameter untuk mengukur kekuatan senyawa bioaktif yang terkandung dalam ekstrak daun bayam petik dapat dilihat dari lebar diameter zona hambat. Semakin lebar zona hambat yang terbentuk maka semakin kuatnya senyawa bioaktif itu menghambat pertumbuhan bakteri. Ekstrak yang menunjukkan zona hambat kecil atau tidak ada daya hambat bukan berarti sampel tersebut kurang aktif, tetapi kemungkinan tidak terdekteksi pada konsentrasi sampel uji yang digunakan atau kadar hambat umumnya belum tercapai. ${ }^{12}$

Hasil penelitian ini sejalan dengan hasil penelitian sebelumnya yang dilakukan oleh Zipporah $^{14}$ pada tahun 2008. Zipporah mengekstraksi daun bayam petik menjadi empat sampel yang berbeda menggunakan pelarut yang berbeda-beda yaitu heksana, etil asetat, diklorometana, dan metanol, kemudian diujikan pada bakteri Gram negatif (Escherichia coli, Salmonnella typhi, Klebsiella pneumonia, Proteus mirabilis, dan Pseudomonas aeruginosa), bakteri Gram positif (Staphylococcus aureus, dan Bacillus spp), dan jamur (Candida albicans). Hasil penelitian tersebut menunjukkan bahwa empat sampel ekstrak daun bayam petik yang diekstraksi menggunakan empat pelarut yang berbeda, tidak memiliki daya hambat terhadap pertumbuhan bakteri Gram positif dan jamur yaitu Staphylococcus aureus, Bacillus spp, dan Candida albicans. Sebaliknya, pada penelitian tersebut ekstrak daun bayam petik memiliki daya hambat untuk menghambat pertumbuhan bakteri Gram negatif yaitu Escherichia coli, 
Salmonnella typhi, Klebsiella pneumonia, dan Proteus mirabilis. Hal ini disebabkan karena perbedaan struktur dinding sel pada bakteri Gram positif dan Gram negatif. ${ }^{13-15}$

Pada penelitian ini daun bayam petik diekstraksi dengan menggunakan etanol 96\%, sedangkan pada penelitian oleh Zipporah ${ }^{14}$ daun bayam petik dibagi dalam empat sampel kemudian diekstraksi menggunakan empat pelarut yang berbeda. Salah satu dari pelarut tersebut ialah etil asetat. Etil asetat merupakan pelarut dengan toksisitas rendah yang bersifat semi polar yang mampu menarik senyawa golongan alkaloid, flavonoid, saponin, tannin, polifenol, dan triterpenoid. Penelitian yang dilakukan oleh Hidayani ${ }^{16}$ yang membandingkan penggunaan pelarut etanol dan etil asetat pada ekstrak daun gambir terhadap aktivitas pertumbuhan bakteri Staphylococcus aureus, Escherichia coli, Salmonnella, dan Shigella, menunjukkan bahwa daun gambir yang diekstraksi menggunakan pelarut etil asetat mempunyai aktivitas antibakteri yang lebih kuat dibandingkan dengan daun gambir yang diekstraksi menggunakan pelarut etanol.

Penelitian yang dilakukan oleh Hidayani ${ }^{16}$ pada tahun 2010 sejalan dengan penelitian yang dilakukan oleh Rahmaningtyas et al. ${ }^{17}$ pada tahun 2012 dengan membandingkan ekstrak etanol daun sisik naga dan ekstrak etil asetat daun sisik naga. Hasil penelitian tersebut menunjukkan bahwa ekstrak yang diekstraksi dengan etil asetat mempunyai aktivitas antibakteri yang lebih kuat dengan diameter zona hambat yang terbentuk yaitu $28 \mathrm{~mm}$ terhadap bakteri Staphylococcus aureus dan $15,5 \mathrm{~mm}$ terhadap bakteri Escherichia coli, sedangkan pada ekstrak etanol daun sisik naga diameter zona hambat yang terbentuk yaitu $19 \mathrm{~mm}$ terhadap bakteri Staphylococcus aureus dan $6 \mathrm{~mm}$ terhadap bakteri Escherichia coli. ${ }^{17}$

Dari penelitian yang dilakukan oleh Hidayani ${ }^{16}$ dan Rahmaningtyas et al. ${ }^{17}$ dapat diasumsikan bahwa pembuatan ekstrak yang menggunakan pelarut etil asetat mempunyai aktivitas antibakteri yang lebih kuat dibandingkan dengan ekstrak yang menggunakan pelarut etanol. Oleh karena itu, penelitian yang dilakukan oleh Zipporah $^{14}$ yang salah satu sampelnya menggunakan pelarut etil asetat seharusnya memiliki senyawa bioaktif yang terekstraksi lebih banyak dibandingkan dengan penelitian ini yang menggunakan pelarut etanol $96 \%$ sehingga diharapkan senyawa bioaktif tersebut dapat menghambat pertumbuhan bakteri. Namun sebaliknya, penelitian yang dilakukan oleh Zipporah $^{14}$ menggunakan ekstrak daun bayam petik dengan pelarut etil asetat juga menunjukkan bahwa daun bayam petik tidak memiliki daya hambat terhadap pertumbuhan bakteri Staphylococcus aureus, sehingga pada penelitian diperoleh hasil bahwa komposisi senyawa bioaktif yang terdapat pada daun bayam petik sangat kecil untuk menghambat partumbuhan bakteri Staphylococcus aureus, tetapi dapat menghambat pertumbuhan bakteri Gram negatif. ${ }^{14,16,17}$

\section{SIMPULAN}

Dari hasil penelitian ini dapat disimpulkan bahwa ekstrak daun bayam petik (Amaranthus Hybridus L.) tidak memiliki daya hambat terhadap pertumbuhan bakteri Staphylococcus aureus.

\section{SARAN}

Perlu dilakukan penelitian lebih lanjut untuk mengetahui daya hambat ekstrak daun bayam petik (Amaranthus hybridus L.) terhadap pertumbuhan bakteri Gram negatif penyebab infeksi di rongga mulut, dan juga perlu dilakukan penelitian untuk mengetahui manfaat lain dari daun bayam petik (Amaranthus hybridus L.)

\section{DAFTAR PUSTAKA}

1. Kementrian Kesehatan Republik Indonesia. InfoDATIN. Pusat Data dan Informasi Kementerian Kesehatan Republik Indonesia. Situasi Kesehatan Gigi Dan Mulut. Jakarta, 2014.

2. Badan Penelitian dan Pengembangan 
Kesehatan Kementrian Kesehatan Republik Indonesia. Riset Kesehatan Dasar 2007, Kementrian Kesehatan Republik Indonesia. Jakarta, 2007; p.131.

3. Badan Penelitian dan Pengembangan Kesehatan Kementrian Kesehatan Republik Indonesia. Riset Kesehatan Dasar 2013, Kementrian Kesehatan Republik Indonesia, Jakarta, 2013; p. 111.

4. Agacayak KS, Atilgan SS, Gorgun B, Yaman F, Ucan MC, Atalay Y. Case report: Cannine fossa abscess; A rare etiological factor: The lower canine tooth. J Int Dent Med Res. 2010:6(1):36-9

5. Fragiskos D. Oral Surgery (1st ed). Berlin: Springer, 2007; p. 205-6.

6. Suzuki J, Komatsuzawa H, Sugai M, Suzuki T, Kozai K, Miyake Y, et al. A longterm survey of methicillin-resistant staphylococcus aureus in the oral cavity of children. Microbiol Immunol. 1997;41:681-6.

7. Knighton HT. Coagulase-positive staphylococci in oral and nasal areas of dental students: A four-year study. J Dent Res. 1965;44:467-70.

8. Farah R. The Miracle of Vegetables. Jakarta: AgroMedia Pustaka, 1965; p.17.

9. Akubugwo IE, Obasi NA, Chinyere GC, Ugbogu AE. Nutritional and chemical value of Amaranthus hybridus L. leaves from Afikpo, Nigeria. African Journal of Biotechnology. 2007;6:2833-9.

10. Madduluri S, Rao KB, Sitaram B. In vitro evaluation of antibacterial activity of five indigenous plants extract against five bacterial pathogens of human. Int $\mathrm{J}$
Pharm Pharm Sci. 2013;5(Suppl 4):679-84.

11. Olyvia YKP, Abrori C, Ida Srisurani WA Uji sensitivitas amoksisilin dan eritromisin terhadap infeksi sekunder dari spesimen pasien infeksi saluran pernapasan akut. e-Jurnal Pustaka Kesehatan. 2015;3(1):18-23.

12. Warbung YY, Wowor VNS, Posangi J Daya hambat ekstrak spons laut Callyspongia sp. terhadap bakteri Staphylococcus aureus. e-Gigi. 2013; 1(2):1-12.

13. Brooks GF, et al. Mikrobiologi Kedokteran Jawetz, Melnick \& Adleberg's (23th ed), Jakarta: EGC, 2004; p. 225.

14. Zipporah CM. Chemical Compositions and Antimicrobial Activity of Amaranthus hybridus, Amaranthus caudatus, Amaranthus spinosus, and Corriandrum sativum [Tesis]. Njoro: Egerton University; 2008

15. Putri WS, Warditiani NK, Larasanty LPF. Skrining fitokimia ekstrak etil asetat kulit buah manggis (Gracinia mangostana L.). Jurnal Farmasi Udayana. 2013;2(4):56-60.

16. Hidayani R. Pengaruh penggunaan pelarut etanol dan etil asetat pada ekstraksi daun gambir (Uncaria gambir Roxb.) terhadap aktivitas antibakteri patogen pangan [Skripsi]. Padang: Universitas Andalas; 2010.

17. Rahmaningtyas R, Nashrianto $H$, Aminingsih T. Identifikasi senyawa dalam ekstrak etanol dan fraksi etil asetat daun sisik naga (Drymoglossum piloselloides) dengan GC-MS dan uji aktivitas antibakteri. E-Jurnal Universitas Pakuan. 2012:1-9. 